\title{
Raised number of jejunal IgG2-producing cells in untreated adult coeliac disease compared with food allergy
}

\author{
T O ROGNUM, K KETT, O FAUSA, U BENGTSSON, A KILANDER, \\ H SCOTT, P I GAARDER, AND P BRANDTZAEG
}

From the Institute of Forensic Medicine, Laboratory for Immunohistochemistry and Immunopathology (LIIPAT), Institute of Pathology, University of Oslo; Section of Gastroenterology, Medical Department A, The National Hospital, Rikshospitalet; Department of Immunology, The National Institute of Public Health, Oslo, Norway; and Asthma and Allergy Research Center, Division of Gastroenterology, Sahlgrens' Hospital, University of Gotenborg, Sweden

summary The subclass distribution of IgG-producing immunocytes was studied by two colour immunohistochemistry with monoclonal antibodies in jejunal biopsy specimens from 10 adults with untreated coeliac disease, 11 coeliac disease patients on a gluten free diet, and seven patients with established food allergy. Paired immunofluorescence staining was performed with subclass specific murine monoclonal antibodies in combination with polyclonal rabbit antibody reagent to total IgG; the proportion of cells belonging to each subclass could thereby be determined. The ratio of IgG2 immunocytes was significantly higher $(\mathbf{p}<0 \cdot 05)$ in untreated coeliac disease patients (median, $35 \cdot 2 \%$; range, $26 \cdot 7-65 \cdot 2 \%$ ) than in those on a gluten free diet (median, $7 \cdot 3 \%$; range, $0-31.9 \%$ ) or those having food allergy (median, $12 \cdot 5 \%$; range, $0-36 \cdot 5 \%$ ). The disparity in the local IgG2 response between patients with untreated coeliac disease and those with food allergy might be due to differences in the nature of the antigenic stimuli, dissimilar genetic 'make-up' of the subjects, or both.

Previous studies in our laboratory have indicated altered local homeostasis of the mucosal immune system in several intestinal disorders. ${ }^{1-5}$ In these conditions luminal antigens or mitogens apparently penetrate the mucosa and induce overstimulation of the local B-cell system; altered homeostasis is reflected by a raised proportion of mucosal IgGproducing immunocytes. ${ }^{1-3}$ Furthermore, in coeliac disease there are increased levels of $\operatorname{IgA}$ and $\operatorname{IgG}$ antibodies to various dietary antigens in serum."

It was recently reported that the local IgG- and IgA-subclass response is different in ulcerative colitis and Crohn's disease of the colon. ${ }^{457 \times}$ Such disparity could signify an interplay between genetic and

Address for correspondence: T () Rognum. MD, Institute of Forensic Medicine, Rikshospitalet. N-(0)27 ()slo 1. Norwaty.

Accepted for publication 22 February 1989 immunological factors and might be of great interest for the understanding of disease processes.

A recent study in the United States" suggested that persistently raised serum antibody concentrations to gliadin in adult coeliac disease after treatment with a gluten free diet (GFD), occurred only in patients with the chromosome 14-encoded IgG2 heavy-chain allotype marker $\mathrm{G} 2 \mathrm{~m}(\mathrm{n})$. This observation could not be confirmed by others, however." In addition to such genetically determined variation, it has been shown that various viral and bacterial antigens or mitogens may stimulate B cells to produce different IgG subclasses both in vitro ${ }^{11}$ and in vivo. ${ }^{12}$

The purpose of the present study was to determine the IgG-subclass distribution of mucosal immunocytes in untreated coeliac disease compared with that found in treated coeliac disease patients and in patients suffering from food allergy. The distribution of the IgG heavy-chain marker $(\mathrm{Gm})$ in the patients 
and in a control group of healthy blood donors was also determined.

\section{Methods}

PATIENTS AND TISSUE SPECIMENS

Twenty eight subjects with adverse reactions to food were studied. They included 10 patients with coeliac disease who were untreated and 11 coeliac disease patients on gluten free diet. The coeliac disease diagnosis was based on clinical investigation, intestinal biopsy ${ }^{13}$ (Table 1), and levels of serum antibodies to gluten ${ }^{\text {14 }}$ (Table 2). All coeliac disease patients responded to gluten restriction, and follow up examinations did not disclose other conditions associated with villous atrophy.

Seven patients with abdominal complaints who had a positive history of food allergy (Table 3 ) and a sufficient number of IgG-producing immunocytes for differential subclass-counting in the biopsy specimens were also included. Five of the latter had positive skin prick test for relevant foods and five had IgE positive mucosal mast cells (Table 3 ) detected by immunofluorescence staining of tissue sections. ${ }^{1510}$

Table 1 Clinicopathological information about the patients with coeliac disease

\begin{tabular}{llllll}
\hline $\begin{array}{l}\text { Untreated } \\
\text { patients }\end{array}$ & $\begin{array}{l}\text { Age } \\
(y r)\end{array}$ & Sex & $\begin{array}{l}\text { Time on } \\
G F D^{*} \\
(y r)\end{array}$ & $\begin{array}{l}\text { Histological } \\
\text { characteristics }\end{array}$ & $\begin{array}{l}\text { Clinical } \\
\text { symptoms: }\end{array}$ \\
\hline $1 \$$ & 25 & F & - & II & 1 \\
2 & 33 & F & - & IV & 2 \\
3 & 52 & F & - & IV & 3 \\
4 & 27 & F & - & IV & 2 \\
5 & 31 & M & - & IV & 2 \\
6 & 59 & F & - & IV & 3 \\
7 & 39 & F & - & IV & 2 \\
8 & 73 & F & - & IV & 2 \\
9 & 81 & F & - & IV & 3 \\
10 & 19 & F & - & IV & 2
\end{tabular}

Patients on gluten free diet

\begin{tabular}{lllcll}
11 & 47 & M & $2 \cdot 5$ & I & 1 \\
12 & 63 & F & $0 \cdot 5$ & I & 1 \\
13 & 39 & F & $0 \cdot 75$ & I & 1 \\
14 & 58 & F & $0 \cdot 25$ & II & 2 \\
15 & 35 & F & 3 & I & 1 \\
16 & 21 & F & 18 & I & 1 \\
17 & 41 & F & 1 & I & 1 \\
18 & 39 & M & 14 & I & 1 \\
19 & 40 & M & $0 \cdot 5$ & III & 1 \\
20 & 62 & F & 5 & II & 1 \\
21 & 46 & F & $0 \cdot 5$ & II & 2 \\
\hline
\end{tabular}

*GFD, gluten free diet: †Histological characteristics: I, normal: II, partial villous atrophy; III, subtotal villous atrophy: IV, total villous atrophy: $\ddagger$ Clinical symptoms: 1 , no symptoms 2 , moderate symptoms 3, severe symptoms; $\$$ This patient had ingested mainly fruit and vegetables before biopsy.
Table 2 Concentrations of serum $\lg G$ and $\lg A$ antibodies to gluten determined by ELISA, mucosal $\lg G$ and $\lg G 2$ immunocyte density, and $G 2 m(n)$ type of various patient categories

\begin{tabular}{|c|c|c|c|c|c|}
\hline \multirow{2}{*}{$\begin{array}{l}\text { Untreated } \\
\text { coeliac disease }\end{array}$} & \multicolumn{2}{|c|}{$\begin{array}{l}\text { EL.ISA values } \\
\text { (od at } 405 \mathrm{~nm})\end{array}$} & \multicolumn{2}{|c|}{$\begin{array}{l}\text { Mucosal immunocyte's } \\
\text { number/grid area* }\end{array}$} & \multirow{2}{*}{$\begin{array}{l}\text { (j2m(n) } \\
\text { positivity }\end{array}$} \\
\hline & $\operatorname{Ig}($ & $\lg A$ & $\lg G$ & $\lg \left(G_{2}\right.$ & \\
\hline 1 & $1 \cdot 15$ & $1.5 .5 t$ & 29 & 9 & + \\
\hline 2 & 0.68 & $T \cdot 50$ & 39 & 14 & + \\
\hline 3 & nd & $\overline{\text { ndt }}$ & 30 & 8 & + \\
\hline 4 & $1 \cdot 67$ & 1.58 & 54 & 35 & - \\
\hline 5 & 0.95 & $T \cdot 17$ & 19 & 6 & + \\
\hline 6 & $1 \cdot 45$ & 1.40 & 28 & 10 & + \\
\hline 7 & $(0 \cdot 80$ & 0.17 & 36 & 12 & - \\
\hline 8 & 0.89 & 0.98 & 24 & 6 & - \\
\hline 9 & $1 \cdot 62$ & 2.55 & 18 & 5 & + \\
\hline 10 & $2 \cdot 19$ & 1.28 & 20 & 8 & + \\
\hline \multicolumn{6}{|c|}{ Treated coeliac disease } \\
\hline 11 & 0.32 & 0.11 & 15 & 5 & - \\
\hline 12 & nd & nd & 8 & 1 & nd \\
\hline 13 & 0.70 & 0.13 & 9 & 3 & + \\
\hline 14 & $1 \cdot 15$ & 0.14 & 36 & 1 & + \\
\hline 15 & $0 \cdot 12$ & 0.27 & 23 & 1 & + \\
\hline 16 & 0.59 & $0 \cdot() 4$ & 16 & 3 & + \\
\hline 17 & 0.21 & $0 \cdot(0)$ & 3 & 1 & + \\
\hline 18 & 0.11 & $(0 \cdot 0) 2$ & 7 & 0 & nd \\
\hline 19 & $0 \cdot 16$ & 0.05 & 26 & 3 & + \\
\hline 20 & $1 \cdot 21$ & $3 \cdot 48$ & 24 & 2 & nd \\
\hline 21 & $1 \cdot(02$ & 0.24 & 16 & 1 & - \\
\hline \multicolumn{6}{|l|}{ Food allergy } \\
\hline 22 & 0.62 & $0 \cdot(x)$ & 9 & 1 & + \\
\hline 23 & $0 \cdot 46$ & $0 \cdot(x)$ & 40 & 0 & - \\
\hline 24 & $1 \cdot 43$ & 0.01 & 11 & 2 & + \\
\hline 25 & $1 \cdot 38$ & 0.08 & 7 & 1 & - \\
\hline 26 & $(0 \cdot 14$ & 0.15 & 6 & 1 & + \\
\hline 27 & $1 \cdot 31$ & $0.53 \S$ & 17 & 6 & + \\
\hline 28 & 0.62 & $\overline{0.33}$ & 6 & 1 & + \\
\hline
\end{tabular}

*Each grid area represent $0.32 \mathrm{~mm}$ l lamina propria: $\leftarrow$ Pathologically raised levels (14) are underlined; $\ddagger$ nd, not determined; $\$$ This patient had positive RAST for wheat.

Table 3 Clinicopathological information about the food allergy patients

\begin{tabular}{|c|c|c|c|c|c|c|}
\hline Patients & $\begin{array}{l}\text { Age } \\
(y r)\end{array}$ & Sex & Symptoms & $\begin{array}{l}\text { Positive } \\
\text { history }\end{array}$ & $\begin{array}{l}\text { Skin prick } \\
\text { test to } \\
\text { relevant } \\
\text { foods }\end{array}$ & $\begin{array}{l}\lg E \\
\text { positive } \\
\text { mucosat } \\
\text { mast } \\
\text { cells }\end{array}$ \\
\hline 22 & 21 & $\mathrm{~F}$ & Diarrhoea & egg & - & + \\
\hline 23 & 39 & $\mathrm{~F}$ & $\begin{array}{l}\text { Diarrhoea } \\
\text { Asthma }\end{array}$ & $\begin{array}{l}\text { egg. milk, } \\
\text { hazelnut }\end{array}$ & + & + \\
\hline 24 & 16 & $F$ & Diarrhoea & $\begin{array}{l}\text { milk. } \\
\text { chocolate }\end{array}$ & - & - \\
\hline 25 & 39 & M & Diarrhoea & milk & + & + \\
\hline 26 & 31 & $\mathrm{~F}$ & Diarrhoea & egg & + & - \\
\hline 27 & 55 & $\mathrm{~F}$ & $\begin{array}{r}\text { Diarrhoea } \\
\text { Quincke's } \\
\text { oedema }\end{array}$ & egg & + & + \\
\hline 28 & 56 & $M$ & $\begin{array}{l}\text { Diarrhoea } \\
\text { Vomiting }\end{array}$ & $\begin{array}{l}\text { egg, } \\
\text { hazelnut, } \\
\text { shellfish }\end{array}$ & + & + \\
\hline
\end{tabular}




\section{IMMUNOHISTOCHEMISTRY}

Small mucosal specimens were extracted in cold phosphate buffered ( $\mathrm{pH} \mathrm{7.6)}$ isotonic saline for $48 \mathrm{~h}$ before ethanol fixation and paraffin embedding. ${ }^{17}$ The prewashing procedure was crucial to avoid interstitial background staining caused by extracellular IgG.

Five serial sections were cut at $6 \mu \mathrm{m}$ from each tissue block. One section was stained with hacmatoxylin and cosin for histological evaluation, whereas each of the remaining was subjected to paired immunofluorescence staining for one of the four $\operatorname{IgG}$ subclasses and for total IgG. These sections were first incubated with murine monoclonal antibody (ascites, 1:800) to IgG1 (Clone 2C7), IgG2 (Clone GOM2), IgG3 (Clone CB1-AH7), or IgG4 (Clone R74) and subsequently with a mixture of fluorescein isothiocyanate labelled rabbit antimouse IgG and rhodamine B sulphonyl chloride labelled antihuman IgG. The sources of monoclonal antibodies, ${ }^{18}$ the characteristics of the fluorochrome conjugates, ${ }^{19}$ and other details of this two-colour staining proceduret have been reported previously.

\section{MICROSCOPY AND CELL COUNTING}

Enumeration of $\operatorname{Ig} G$ subclass producing cells Immunocytes with distinctly cytoplasmic fluorescence were counted in a Leitz Orthoplan microscope equipped with a $\times 10$ immersion objective, a $\times 10$ ocular, and a Ploem-type vertical illuminator with interference filters for selective observation of fluorescein (green) or rhodamine (red) emission colours. The cells were counted within the outer frame of a square occular grid (Leitz code no $519902)$, representing an area of $0.32 \mathrm{~mm}^{2}$. The median evaluated number of grids in each specimen was five, (range, 1-10 grids), and the median counted number of cells with cytoplasmic red fluorescence was 140 (range 100-1000 cells). In each section these red cells represented the internal reference for the total number of IgG-producing immunocytes, and they were all examined for concomitant green (subclass) fluorescence. The proportion of immunocytes positive for one of the four subclasses was calculated

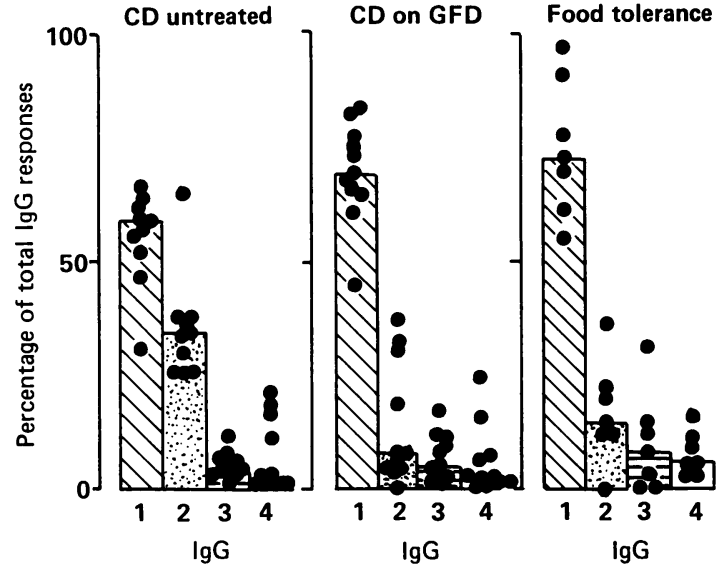

Fig. 1 Scatter diagram of the percentage distribution of

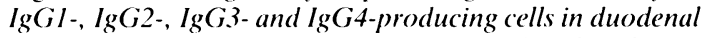
mucosa of three patient categories: untreated coeliac disease (CD), CD patient on gluten free diet (GFD), and patients with food allergy.

in relation to the total number of IgG-producing cells present in the evaluated area of the actual section. In a previous study the intraobserver and interobserver reproducibility of such cell enumerations showed good correlation ( $r=0.96$ and 0.89 , respectively) and no systematic error. ${ }^{+}$

Comparison of monclonal subclass specific antibodies and polyclonal anti-IgG

Tissue sections from two of the patients were first incubated with a mixture of the four monoclonal antibodies (each at a final dilution of 1:800) and then with the mixed fluorochrome conjugates as described above. Red and green cells were counted in altogether 23 square grids ( 15 from one section and eight from the other). To avoid bias, these enumerations were performed without checking for double staining.

SERUM ANTIBODIES TO GLUTEN

Serum IgG and IgA activities to gluten proteins were measured by an ELISA method." 21

Figs 2(a-d) Paired immunofluorescence staining for Ig 3 subclasses in four serial sections of duodenal mucosa from a patient with untreated coeliac disease. Red fluorescence indicates total IgG-producing cells and green indicates (a) $\lg G I$, (b) $\lg (32$, , (c) $\lg G 3$, or (d) $\lg G 4$. In these double exposed pictures the respective subclass-producing cells are identified by mixed (yellow) colour. Note that purely green cells are extremely rare (arrow). (c) Paired immunofluorescence staining with polyclonal anti-IgG conjugate (red) and mixture of monoclonal antibodies (green) to the four IgG-subclasses. In this double exposed picture yellow colour indicates true identification of subclass producing cells. (f) Relation between results of cell enumerations performed in control experiment depicted in Figure e. The number of fluorescein-positive (green) cells per grid unit represented all those reacting with the four monoclonal antibodies to $\operatorname{Ig} G$ subclasses, whereas the number of rhodamine positive (red) cells per unit represented those reacting with the polyclonal anti-lgG conjugate $(r=0.996)$. The identity line is indicated. 
IgG HEAVY CHAIN MARKERS

Gm typing was performed by hacmagglutination inhibition as described elsewhere ${ }^{21}$ in the patients studied and in 50 healthy blood donors.
STATISTICAL ANAIYYSIS

Correlation analyses were performed by the Pearson $r$-test. Differences between median proportions of IgG subclass producing cells and serum antibody
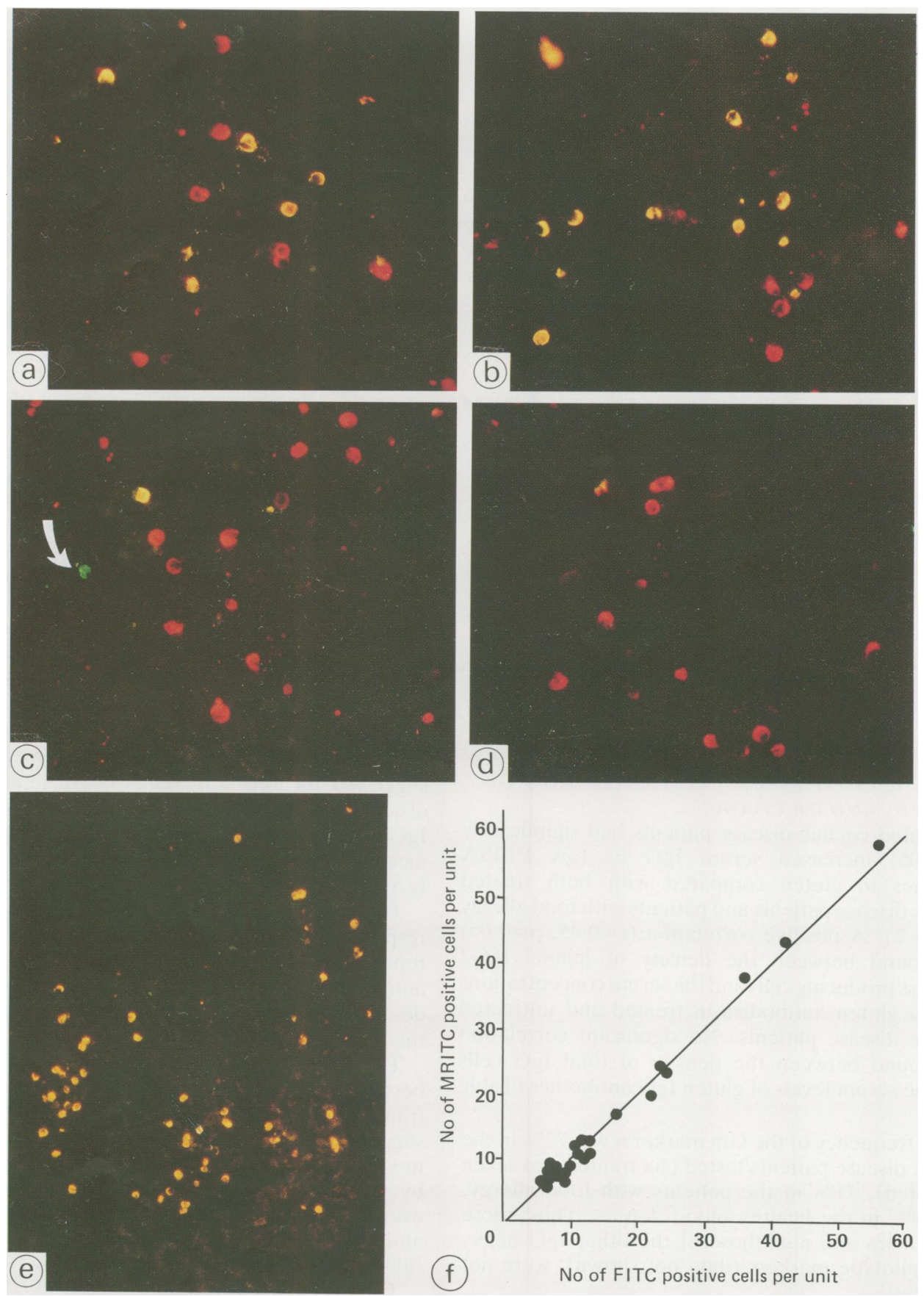
activities among the three patients' groups were determined by Wilcoxon's two-tailed test for unpaired samples. Possible differences in Gm marker frequencies were estimated by the $\chi^{2}$ test.

\section{Results}

SUBCIASS DISTRIBUTION OF IgG-PRODUCING CELISS

The median proportion of IgG2-producing cells in untreated coeliac disease patients $(35 \cdot 2 \%)$ was significantly higher $(\mathrm{p}<0.05)$ than in coeliac disease patients on a gluten free diet $(7.3 \%)$ or patients with food allergy (12.5\%) (Figs 1 and 2a-d). There were no statistically significant differences between the medians of the other IgG-subclasses in the three patient categories.

The sum of the four IgG subclass percentages in serial sections from each biopsy specimen was usually close to $100 \%$ (median, $99.9 \%$; range, $90.4 \%-$ $113.5 \%)$. These results attested to the reliability of the subclass determinations.

COMPARISON OF MONOCI.ONAI. SUBCI.ASS SPIECIFIC ANTIBODIES ANI) POI.YCI.ONAL ANTIIgG

In this control experiment virtually all positive immunocytes showed both red and green fluorescence (Fig. 2e). The coefficient of correlation $(r)$ was 0.996 (Fig. 2f). Purely green or red cells were extremely rare. This result showed that the paired staining procedure used for individual IgG subclasses was highly reliable.

LOCAI. IgG RESPONSI, SERUM ANTIBODIES TO GI.UTIN, AND GIm TYPING

Untreated cocliac disease patients had significantly $(p<0 \cdot 05)$ increased serum IgG or IgA ELISA activities to gluten compared with both treated coeliac disease patients and patients with food allergy (Table 2). A positive correlation $(r=0 \cdot 45, p=0 \cdot 05)$ was found between the density of jejunal IgG2 subclass producing cells and the serum concentrations of $\mathrm{IgG}$ gluten antibodies in treated and untreated coeliac disease patients. No significant correlation was found between the density of total IgG cells and the serum levels of gluten IgG antibodies (Table 2).

The frequency of the Gm marker $n$ was $72 \%$ in the coeliac disease patients tested (six treated and seven untreated), $71 \%$ in the patients with food allergy, and $70 \%$ in the healthy blood donors. Thus, these frequencies and also those of the other IgG heavy chain allotype markers (data not shown), were not different.

\section{Discussion}

A mucosal $\operatorname{lgG}$ response has previously been suggested to be of pathogenic importance in cocliac disease, $"$ and it was of interest to study the subclass pattern of this reponse. Here we report that the proportion of duodenal IgG2-producing cells was found to be significantly increased in untreated cocliac disease patients compared with treated ones and with patients who had food allergy.

Because of the scarcity of $\mathrm{IgG}$ immunocytes in healthy gut mucosa,' we were unable to evaluate the subclass pattern in normal control specimens.

Our results indicated that the mucosal immune response in cocliac disease includes - in addition to $\lg \mathrm{A}, \operatorname{IgM}$ and $\operatorname{IgG}$, in that order' a preferential local expansion of the IgG2 cell population. The proportion of mucosal IgG2 cells found in untreated coeliac disease was similar to that seen in Crohn's disease of the colon. ${ }^{+}$Conversely, in ulcerative colitis we observed a disproportionate expansion of the $\operatorname{IgG} 1$ cell population. ${ }^{+}$In normal nasal mucosa we often found a preference of IgG3- over IgG2-producing cells,"- thus contrasting that seen in inflamed intestinal mucosa - probably because of differences in the nature of antigenic stimulation at the two mucosal sites.

The relatively prominent jejunal $\mathrm{IgG} 2$ response in untreated cocliac disease may hence be directly related to gluten ingestion. A possible role of $\operatorname{lgG} 2$ in the pathogenesis of coeliac disease, however, remains obscure. Aś IgG2 has relatively little complement activating capacity ${ }^{23}$ and shows poor Fc receptor binding, ${ }^{2+}$ it is unlikely that this subclass is important in the perpetuation of coeliac disease as we previously suggested for $\operatorname{IgG}$ antibodies on the basis of our observations of the total mucosal IgG response.' $\operatorname{lgG} 2$ may, instead, be involved in local protective mechanisms in concert with the stimulated secretory $\operatorname{Ig} \mathrm{A}$ and IgM system.'

The present finding of a prominent mucosal $\mathrm{IgG} 2$ response is of interest in light of the conflicting results reported on the $\operatorname{IgG}$ subclass distribution of gliadin antibodies in serum. Such antibodies have been described in all of the IgG subclasses, but mainly in the IgG1 subclass. ${ }^{3-27}$

The relatively weak but significant correlation between local IgG2 cell response and serum concentrations of IgG antibodies to gluten seen in our study, suggested a possible contribution of serum IgG from mucosal production. Regional lymph nodes seeded by gluten stimulated mucosal immunocytes, however, may be an even more important source of such antibodies. We are currently evaluating the serum IgG subclass response to gluten by ELISA.

The raised proportion of mucosal IgG2 producing 
cells observed in untreated coeliac disease may signify an interplay between genetic and environmental factors. Association between immunoglobulin genetic markers and levels of antibody production has been reported..$^{-x}$ Thus, in American caucasian adult coeliac disease patients the IgG2 allotype marker $\mathrm{G} 2 \mathrm{~m}(\mathrm{n})$ seems to be associated with a persistent IgG response to gluten in treated coeliac disease patients." Conversely, neither our study nor that of Finnish coeliac disease children"' has been able to confirm that this marker is associated with persistently raised serum concentrations of IgG gluten antibodies after introduction of gluten free diet. Moreover, we found no difference in the $\mathrm{G} 2 \mathrm{~m}(\mathrm{n})$ distribution between coeliac disease patients on gluten free diet with a relative high or a low mucosal IgG2 response. Our study supports previous reports" "I of a high and equal frequency of $\mathrm{G} 2 \mathrm{~m}(\mathrm{n})$ in cocliac disease patients and controls.

Little is known about the biological significance of the various IgG subclasses, and further studies are clearly necessary to elucidate the role of the IgG subclass response in cocliac disease. Longitudinal studies of the same patients will be of great interest and should include both the local IgG response pattern and monitoring of serum concentrations of dietary antibodies.

Supported by the Norwegian Research Council for Science and the Humanities.

\section{References}

1 Brandtzacg P, Valnes K, Scott H, Rognum TO, Bjerke $\mathrm{K}$, Baklien $\mathrm{K}$. The human gastrointestinal secretory immune system in health and discase. Scand J Gastroenterol 1985; 20 (suppl 114): 17-38.

2 Scott H, Ek J, Baklien K, Brandtzacg P. Immunoglobulin-producing cells in jejunal mucosa of children with coeliac disease on a gluten-free diet and after gluten challenge. Scand J Gastroenterol 1980; 15: 81-8.

3 Rognum TO, Brandtzacg P. Baklien K, Hognestad J. Immunoglobulin-producing cells in the "transitional" mucosa adjacent to adenocarcinomas of the human large bowel. Int J Cancer 1979; 23: 165-73.

4 Kett K, Rognum TO, Brandtzacg P. Mucosal subclass distribution of immunoglobulin G-producing cells is different in ulcerative colitis and Crohn's disease of the colon. Gastroenterology 1987; 93: 919-24.

5 Kett K. Brandtzacg P. Local $\operatorname{IgA}$ subclass alterations in ulcerative colitis and Crohn's disease of the colon. Gut 1987; 28: 1013-21.

6 Scott H, Fausa O, Ek J, Brandtzacg P. Immune response patterns in coeliac discase. Serum antibodies to dietary antigens measured by an enzyme linked immunosorbent assay (ELISA). Clin Exp Immunol 1984; 57: 25-32.
7 Scott MG, Nahn MH, Macke K, Nash GS, Butovich MJ, MacDermott RP. Spontancous secretion of IgG subclasses by intestinal mononuclear cells: difference between ulcerative colitis, Crohn's disease, and controls. Clin Exp Immunol 1986; 66: 209-15.

8 MacDermott RP. Nash GS. Butovich MJ, et al. Altered patterns of secretion of monomeric $\lg A$ and $\lg A$ subclasses 1 by intestinal mononuclear cells in inflammatory bowel discase. Gastroenterology 1986; 91: 379-8.5.

9 Weiss JB, Austin RK, Scanfield MS, Kagnoff MF. Gluten sensitive enteropathy. Immunoglobulin G heavy-chain $(\mathrm{Gm})$ allotypes and the immune response to wheat gliadin. J Clin Invest 1983; 72: 96-101.

10) Fredric AJ, Pandey IP, Verkasola M, Teppo AM. Fudenberg HH. Immunoglobulin allotypes and the immune response to wheat gliadin in a Finnish population with celiac disease. Expl Clin Immunogenet 1985; 2: 18.5-90.

11 Walker L, Johnson GD, Mac Lennan ICM. The IgG subclass responses of human lymphocytes to B-cell activators. Immunology 1983; 50: 269-72.

12 Rantonen N, Pelkonen J, Sipinen S, Kayhty H, Mäkela O. Isotype concentrations of human antibodies to group A meningococcal polysaccharide. $J$ Immunol 1986; 187: 267()$-5$.

13 Doniach D, Shiner M. Duodenal and jejunal biopsies. Gastroenterology 1957; 33: 71-86.

14 Scott H, Rognum TO; Midtvedt T, Brandtzacg P. Agerelated changes of human serum antibodies to dictary and colonic bacterial antigens measured by an enzymelinked immunosorbent assay. Acta Path Microbiol Immunol Scand Sect C 1985; 93: 65-70.

15 Rognum T. Brandtracg P. IgE-positive cells in human intestinal mucosa are mainly mast cells. Int Arch Allergy Appl Immunol 1989; 89: 256-60).

16 Bengtsson U, Rognum TO. Ahlstedt S. Killander A. Hansson L.Ä. Brandtzacg P. IgE in duodenal biopsy specimens from patients with food related diarrhoca Gut (Submitted).

17 Brandtzacg P. Mucosal and glandular distribution of immunoglobulin components. Immunohistochemistry with a cold ethanol-fixation technique. Immunology 1974; 26: 1101-14.

18 Jefferis R, Reimer CB, Skavril F, et al. Evaluation of monoclonal antibodies have specificity for human IgG sub-classes: Results of an IUIS/WHO collaborative study. Immunol Letters 1985; 10: 223-52.

19 Brandtzacg P, Kett K, Rognum TO, Søderstrøm R, Bjørkander J, Søderstrøm T, Petruson B, Hansson LÅ. Distribution of mucosal IgA and IgG subclass-producing immunocytes and alterations in various disorders. Mongr Allergy 1986; 20: 179-94.

20 Scott H, Rognum TO, Brandtzacg P. Performance testing of antigen-coated polysterene microplates for ELISA measurements of serum antibodies to bacterial and dictary antigens. Acta Pathol Microbiol Immunol Scand Sect C 1985; 93: 117-23.

21 Gaarder PI, Natvig JB. Distribution of isotypic and allotypic human IgG antigens in non-human primates. J Immunol 1974; 113: 635-44.

22 Brandtzacg $P$, Karlsen G, Hanson G, Petruson B. Bjørkander J, Hansson LA. The clinical condition of 
IgA-deficient patients is related to the proportion of IgD- and IgM-producing cells in their nasal mucosa. Clin Exp Immunol 1987; 67: 626-36.

23 Spicgelberg HL. Biological activities of immunoglobulins of different classes and subclasses. Adv Immunol 1974; 19: 259-93.

24 Unkeless JC, Fleit H, Mellman JS. Structural aspects and heterogeneity of immunoglobulin Fc-receptors. Adv Immunol 1981; 31: 247-70.

25 Ciclitira PJ, Ellis HJ, Richards D, Kemeny DM. Gliadin IgG subclass antibodies in patients with cocliac discase. Int Archs Allergy Appl Immunol 1986; 80: 258-61.
26 Husby S, Foged N, Oxelius VA. Svehag SE. Serum IgC subclass antibodies to gliadin and other dietary antigens in children with cocliac discase. (lin Exp Immunol 64: 526-35.

27 Rawcliffe PM, Jervell DP, Faux JA. Specific IgG subclass antibodies, IgE and IgG S-TS antibodies to wheat gluten fraction $\mathrm{B}$ in patients with cocliac discase. Clin Allergy 1985; 15: 15.5-62.

28 van Loghem E. The immunoglobulin genes: genetics, biological and clinical significance. Clin Immunol Altergy 1984; 4: 607-22. 